\title{
Community and Interprofessional Collaboration in Physic Rehabilitation Area, Which Place For Patient Safety for the Individuals?
}

\author{
Daphney St-Germain* \\ Laval University, Canada
}

*Corresponding author: Daphney St-Germain, RN, Ph. D. (Public Health), Associate Professor, Nursing Sciences Faculty, Laval University , Researcher at a Quebec physic rehabilitation center (CIRRIS), Quebec, Canada

Submission: 眥 January 18, 2018; Published: 非 February 05, 2018

\section{Commentary}

Magassouba [1] research points out that the analysis of the perceptions of the healthcare professionals towards interprofessional collaboration reveals some barriers face to a vulnerable population, such as:

a) Not clear borders for the team between multidisciplinarity and interdisciplinarity Laxness in the cases confidentiality respect.

b) A dichotomous vision between professional autonomy and interprofessional collaboration.

They, are there only some of the obstacles identified in an organized institutional environment, like a center of health services, where the interprofessional collaboration should be natural and agreed. We can then suspect what look like these obstacles after the hospitalization of a person who continues to need care and services during several years and for whom the quality of life depends on it. The issues and impact of these outcomes with a vulnerable population, such as that having incapacities and physical deficiencies, bring a unique perspective to the reality of the community setting. Ideally, the community would aim to be a place of tight continuity of care with hospital where the person can take care of its health so as to exercise a full and whole participation as citizen. This role of closeness and support which the healthcare professionals have to back turns out particularly determinant for the populations more vulnerable as the people in physical rehabilitation.

Following the example of chronic diseases, the people affected by physical deficiencies often require a global and chronic support in community. On the other hand, are they served as well as the other patients related to professional expertise and interprofessional collaboration? Could it have risks for their safety? Indeed, in community, the musculoskeletal disorders, intellectual, visual, spinal cord injury or others, responsible for the need for services in physical rehabilitation for young or aging people, require an early recognition of the complication signs of and an adequate communication between the healthcare professionals concerned. Furthermore, most of the time, these people feel a change of the self-image due to the aftereffects inherent to their incapacity.
Generally, such aftereffects bring the people over a long process of mourning which perturbs them psychologically causing anxiety, rabies, depression, isolation and even, self-destructive behaviors (Mauk [2], St-Germain [3]). In rehabilitation setting, the staff, especially nurses who work according to a humanist approach and act as pillar of the interdisciplinary team, can make so that these people progress as to restore the link with themselves; to accept their condition, become integrated and participate possibly in the social life (Smith [4], St-Germain [5]). However, coming back home, the medical and psychological support is no longer on the agenda. Besides, the complications linked to their physical rehabilitation are often unappreciated in community services where the transition of the medical and psychological support does not come true. If, formerly, omnipresent between healthcare stakeholders, the communication is now broken outside these walls. This gives up the person by itself, often without resources, face to an unfinished recovery and even unachievable. Serious complications, such as autonomic dysreflexia, for example, in spinal cord injury, can affecting their safety and their quality of life (Milligan [6], Burns $[7,8])$.

The quest of health should be made then as an absolute search for safety, in a multidimensional way. Just like World Health Organization (WHO [9]) had mentionned : Health is a state of complete physical, mental and social well-being and not merely the absence of disease or infirmity ; concept of safety should result of a significant physical, psychological, psychosocial and spiritual multidimensional coverage for the person. It is so important for vulnerable people affected by physical deficiencies, often in handicap situation. In a Caring-DCP (Disability Creation Process) Model perspective (St-Germain [10]) where it is recognized that the environment has the power "to handicap" a person by impeding the achievement of its life habits and, by the way, its social participation. So, lack of adequate coverage in community by the healthcare professionals can be considered an obstacle from environment which can maintain the person in a status "of handicapped person". Well beyond the physical image of its incapacities and its deficiencies, the "handicap" becomes then a relative entity which 
defines itself by the environment or the system in which it takes place. The safety of these people is then tributary of this system by depending on its social and professional aspects. A serious concern for patients safety in community then must be adressed since this affect the person in its multiple dimensions.

Possible avenues, Possible actions tracks consist about cares and services supply beyond the curative, preventive, proximitive with these vulnerable people and so as to protect the full and whole citizen participation for individuals. It goes with empowerment which must be valued and which has to guide the collaboration of the professionals, since the admission in rehabilitation center and continuing in community. It seems an obvious fact but in reality, these two entities, interprofessional collaboration and community environment, do not seem so easy to make coexisting concretely; particularly when it is about services supply aiming vulnerable populations (St-Germain 2016). This difficulty results on the notions bound to interprofessional collaboration were they had been developed and experimented from a normative frame intrahospital: sharing the same physical place, team meetings scheduled in advance, knowing each other as professional, etc. In spite of the fact that, nowadays, the interprofessional collaboration stands out as an unavoidable practice in healthcare system, its enhancement in community still remains parsimonious and asks to be opened up. Ageing of the population, more complex health problems, professionals more specialized and the accelerated continuum of services bring naturally all stakeholders to work together; but this should be more realistic for vulnerable populations living in community. Their safety resulting from the continuity of the care and the services which so affects their quality of life, should import us just as much. These populations are not exceptions in the need for understanding together most prevail health problems reaching them and find collectively solutions (Careau [11]).

Besides that, ironically, vulnerable people such as individuals in physical handicap situation are often targeted for media community actions. Nevertheless, as they are aimed by participative approach principles and empowerment, as this target can so often fail in the expected results. Consider the phenomenology of the person with the unicity of its need should become then essential in the prospect of any equity and social justice to overcome any obstacle, for today and for the future.

\section{References}

1. Magassouba D (2013) Mise en oeuvre de la pratique multidisciplinaire dans une équipe de soins travaillant auprès des utilisateurs de drogues par injection dans un contexte de marginalité et d'exclusion sociale, Projet d'intervention présenté à la Faculté des études supérieures et postdoctorale de l'Université Laval dans le cadre du programme de maîtrise en santé communautaire pour l'obtention du grade de Maître ès sciences (M.Sc.), Département de médecine sociale et préventive, Faculté de médecine, Université Laval, Québec, plus annexe p. 82.

2. Mauk KL (2012), Overview of rehabilitation, Dans KLM (Eds.), Rehabilitation Nursing:A Contemporary Approach to Practice. Sudbury, Jones \& Bartlett Learning, USA.

3. St Germain D (2016) Collaboration interprofessionnelle, milieu communautaire et vulnérabilité: quels sont les défis identitaires à relever? Ds : Desgroseilliers, Valérie; Vonarx, Nicolas; Guichard, Anne et Roy, Bernard. La santé communautaire en 4 actes : repères, acteurs, démarches et défis Québec, Canada, pp. 305-310.

4. Smith MC, Turkel MC, Wolf ZR (2013) Caring in Nursing Classics. In: Smith MC, Turkel MC, Wolf ZR (Eds.), Caring in Nursing Classics. New York: Springer Publishing Company, LLC, USA.

5. St-Germain D (2014) The Rehabilitation Nurse Then and Now: From Technical Support to Human Potential Catalyst by Caring-Disability Creation Process Model in an Interprofessional Team. Journal of Nursing Education and Practice 4(7): pp. 54-61.

6. Milligan J, Lee J, McMillan C, Klassen H (2012) Dysréflexie autonome, Reconnaître un grave problème courant chez les patients victimes d'une lésion médullaire, Can Fam Physician vol. 58(8): e427-e432.

7. Burns AS, St-Germain D, Connolly M, Delparte JJ, Guindon A, et al. (2015) Neurogenic bowel after spinal cord injury from the perspective of support providers: a phenomenological study. PMR 7(4): 407-416.

8. Burns AS, St-Germain D, Connolly M, Delparte JJ, Guindon A, et al. (2015) Phenomenological study of neurogenic bowel from the perspective of individuals living with spinal cord injury. Arch Phys Med Rehabil 96(1): 49-55.

9. World Health Organization (WHO, 1946) The Constitution adopted by the International Health Conference held in New York from 19 June to 22 July. Geneva Switerland.

10. St-Germain D, Boivin B, Fougeyrollas P (2011) "The Caring-Disability Creation Process model: a new way of combining Care in nursing and Rehabilitation for Better Quality of Services and Patient Safety". Disability and Rehabilitation 33: 2105-2113.

11. Careau E, Houle N, Dumont S (2011) Continuum des pratiques de collaboration interprofessionnelle en santé et services sociaux, RCPI, Ireland.

\section{Your subsequent submission with Crimson Publishers will attain the below benefits}

International License

For possible submission use the below is the URL Submit Article
- High-level peer review and editorial services

- Freely accessible online immediately upon publication

- Authors retain the copyright to their work

- Licensing it under a Creative Commons license

- Visibility through different online platforms

- Global attainment for your research

- Article availability in different formats (Pdf, E-pub, Full Text)

- Endless customer service

- Reasonable Membership services

- Reprints availability upon request

- One step article tracking system 